\title{
New insights into volcanic processes and diamond grades from deep mining at Argyle
}

\author{
Murray J. Rayner ${ }^{1}$, Stephen W. Moss ${ }^{2,3}$, A. Lynton Jaques ${ }^{4}$, Volker Lorenz ${ }^{5}$, Grant L. \\ Boxer $^{6}$, Chris B. Smith ${ }^{7}$, and Kimberley Webb ${ }^{2}$ \\ ${ }^{1}$ Argyle Diamonds, Rio Tinto, Perth, Australia, murray.rayner@riotinto.com \\ ${ }^{2}$ Mineral Services Canada, Vancouver, Canada, kimberley.webb@mineralservices.com \\ ${ }^{3}$ Terram Vero Consulting Inc., Vancouver, Canada, smoss@terramvero.com \\ ${ }^{4}$ Australian National University, Canberra, Australia, lynton.jaques@anu.edu.au \\ ${ }^{5}$ University of Würzburg, Würzburg, Germany,vlorenz@geologie.uni-wuerzburg.de \\ ${ }^{6}$ Consultant Geologist, Perth, Australia, boxerg@iinet.net.au \\ ${ }^{7}$ University of Bristol, Bristol, United Kingdom, chris_b_smith@btopenworld.com
}

\section{Introduction}

The Argyle mine in the east Kimberley region of Western Australia is one of the world's largest diamond deposits, and has produced some 835 million carats (cts) since mining began in 1983. At its peak in the period 1993-1998 Argyle produced more than 40 million cts per annum. The Argyle AK1 pipe is one of the world's highest grade mines with production averaging $~ 3-4 \mathrm{cts} /$ tonne. Information obtained during deep open pit mining over the past 28 years, extensive drilling programs, and underground mining since 2013 has provided the basis for a re-examination of the geology and volcanology of the AK1 lamproite pipe, requiring some revisions to earlier accounts.

\section{Geology}

Comprehensive 3-D modelling shows AK1 is a composite body comprising four coalesced, steepsided diatremes that are aligned along a NNE-trending fault and taper to narrow feeder zones at depth. The body is in-filled by deposits of volcaniclastic olivine lamproite and cut by late olivine lamproite dikes (Boxer et al. 1989; Jaques et al. 1989). Following emplacement, AK1 was tilted $30^{\circ}$ to the north and cut by the sinistral NNW-SSE Gap fault system, and by the dextral E-W Razor Ridge fault, resulting in N-S elongation of the body (Rayner et al. 2017).

The largest domain in AK1 is the so-called southern diatreme (Fig. 1), which comprises two coalesced diatremes at depth and features a zone of distinctly higher grade at its southern end from the premining post-eruption surface to $900 \mathrm{~m}$ below surface. Previous studies have shown that the Argyle diamond population is characterized by a small diamond size with a log-normal distribution and high stone frequency, with large variations in diamond grade (along with some small value variations) within the pipe due to differences in stone frequency (Hall and Smith 1985). The apparent consistency of the diamond population in the southern diatreme at Argyle was complemented historically by assumptions of a simple internal geology model.

However, recent mining within the block cave mine at depth has displayed grade and quality fluctuations which appear to be in conflict with the historical simplistic single source lamproite model within the southern diatreme. Here, we report results from recent studies and reconciliation work aimed at defining the volcanological controls on diamond grade within the ore body. These results suggest a more complex internal geology in the southern diatreme, and point to the occurrence of at least four distinct lamproite lithofacies (Fig. 2), with two of these having unique diamond contents. 


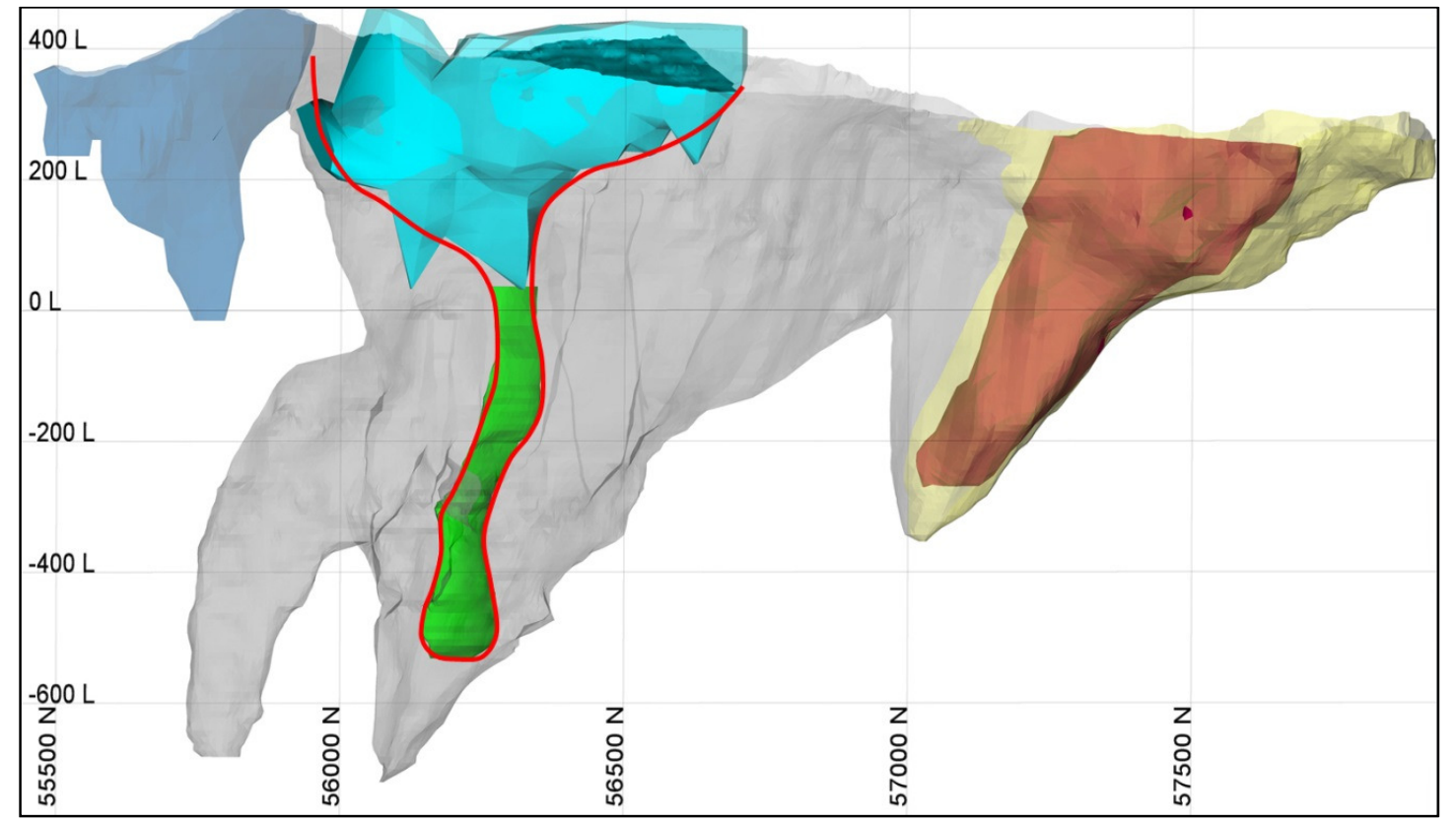

Figure 1: Long-section of the Argyle AK1 pipe facing west showing the high grade domain at the south end of the southern diatreme (light blue), the newly-identified high grade domain (green), and interpreted conduit-like geometry (red outline) of the combined deep and shallow high grade zones. Also displayed are the north sandy (yellow), non sandy (red), southern tail (dark blue) and south sandy low (grey) domains; the latter comprises undifferentiated Lamp1a, Lamp2 and Lamp4 lithofacies. Scale in metres.

Lamp1a comprises thinly-bedded quartzrich volcaniclastic (altered) olivine lamproite, and is distinct because of a) fine-scale $(1-15 \mathrm{~cm})$ bedding, and $\mathrm{b}$ ) pale grey quartz-rich matrix. Beds contain free olivine ( $8-15 \%$ of the rock) and characteristic blocky to irregular juvenile pyroclasts (typically $10-25 \%$ ) ranging up to $20 \mathrm{~mm}$ in size with variably vesiculated, formerly glassy to very fine grained pale/dark brown or black groundmass. This is a common lithofacies throughout much of the southern diatreme.

Lamp1h (from the newly-recognised high grade domain) is similar to Lamp1a but has distinctly less detrital quartz and a much higher proportion of free (altered) olivine. Lamp2 is a massive, quartz-rich volcaniclastic lamproite with distinctive wispy and irregular-shaped formerly glassy pyroclasts. This lithofacies is found in both the north and south of the southern diatreme but predominantly in its northern section and at depth. Lamp4 comprises juvenile lapilli-rich, quartz-poor, and crudelybedded volcaniclastic lamproite. It has
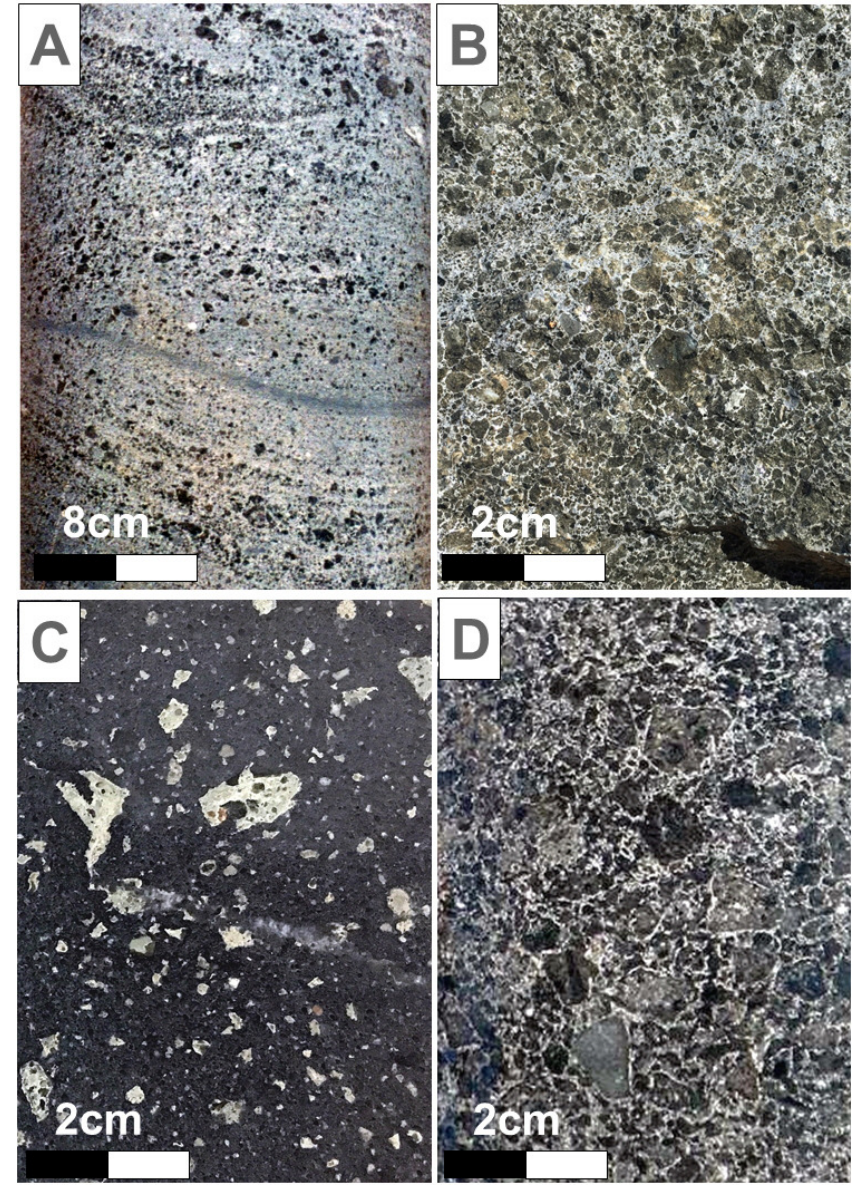

Figure 2: Main lamproite lithofacies from southern diatreme of AK1: a) Lamp1a; b) Lamp1h; c) Lamp2; and d) Lamp4 -2 - 
been mapped in the central and eastern portions of the southern diatreme.

Key textural differences between the lamproite lithofacies in the southern diatreme include the relative proportions of juvenile lapilli, olivine and detrital quartz. These differences are interpreted to reflect: a) the proportion of mantle-derived olivine; b) the degree to which olivine has been liberated from the lamproite host melt; c) the speed of melt cooling; d) the organization of pyroclastic components, and e) the amount of dilution by quartz grains.

\section{Lamproite Grades}

Grade variations realized during mining are shown to be the result of changes in the relative proportions of the lamproite lithofacies being mined: high grades are associated with volcaniclastic lamproite that is olivine-rich and has low dilution (i.e. Lamp1h), while lower grades are linked to olivine-poor and highly diluted volcaniclastic lamproites (i.e. Lamp2). High grade (>10 ct/t) volcaniclastic lamproite at the south end of the southern diatreme provides a basis for linking the high grade zones at the original mining surface with those encountered at depth during block cave mining and deep underground drilling (Fig. 1). The resulting geometry of the combined high grade zone of AK1 resembles that of a volcanic feeder or conduit, and requires modifications to previous emplacement interpretations (Rayner et al. 2017).

\section{Conclusions}

A complex series of volcaniclastic lamproites that have been displaced by post-eruption faulting events have been unraveled to form a new view of the previously more simplistic volcanological model for Argyle. This new view provides a firmer basis for understanding both the volcanological history and the controls on diamond grade within the Argyle pipe.

\section{References}

Boxer GL, Lorenz V, Smith CB (1989) The geology and the volcanology of the Argyle (AK1) lamproite diatreme, Western Australia. In: Ross J et al (eds), Kimberlites and related rocks, vol 1: Their composition, occurrence, origin and emplacement. Geol Soc Aust Spec Publ 14:140-152

Hall AE, Smith CB (1985) Lamproite diamonds - are they different? In: Glover JE, Harris PG (eds), Kimberlite occurrence and origin: a basis for conceptual models in exploration, Geology Department and University Extension, University of Western Australia, Publ No 8, 167-212

Jaques AL, Haggerty SE, Lucas H, Boxer GL (1989) Mineralogy and petrology of the Argyle (AK1) lamproite pipe, Western Australia. In Ross J et al (eds), Kimberlites and related rocks, vol 1: Their composition, occurrence, origin and emplacement. Geol Soc Aust Spec Publ 14:153-169

Rayner MJ, Jaques AL, Boxer GL, Smith CB, Lorenz V, Moss SW, Webb K, Ford D (2017) The geology of the Argyle (AK1) diamond deposit, Western Australia. Soc Econ Geol Spec Publ (in press) 